MODIFICATION OF TITANIUM DIOXIDE NANOPARTICLES WITH COPPER OXIDE CO-CATALYST FOR PHOTOCATALYTIC DEGRADATION OF 2,4-DICHLOROPHENOXYACETIC ACID

\author{
(Nanozarah Titanium Dioksida Terubahsuai Ko-Mangkin Kobalt Oksida untuk Degradasi \\ Asid 2,4-diklorofenoksiasetik) \\ Leny Yuliati ${ }^{1}$, Wai Ruu Siah ${ }^{1}$, Nur Azmina Roslan ${ }^{2}$, Mustaffa Shamsuddin ${ }^{2}$, Hendrik O. Lintang ${ }^{1}$ \\ ${ }^{I}$ Centre for Sustainable Nanomaterials, Ibnu Sina Institute for Scientific and Industrial Research \\ ${ }^{2}$ Department of Chemistry, Faculty of Science \\ Universiti Teknologi Malaysia, 81310 UTM Johor Bahru, Johor, Malaysia \\ *Corresponding author: leny@ibnusina.utm.my
}

Received: 9 December 2014; Accepted: 3 January 2016

\begin{abstract}
2,4-dichlorophenoxyacetic acid (2,4-D) is a common herbicide that has been used widely. Due to its excessive usage, the 2,4-D herbicides can cause contamination over agricultural land and water bodies. In the present work, a simple impregnation method was used to modify the commercial titanium dioxide $\left(\mathrm{P} 25 \mathrm{TiO}_{2}\right)$ nanoparticles with the copper oxide. The prepared samples were characterized by X-ray Diffraction (XRD), reflectance UV-visible and fluorescence spectroscopies. It was observed that the incorporation of copper oxide did not significantly affect the crystal structure of $\mathrm{P} 25 \mathrm{TiO}_{2}$. On the other hand, the presence of copper oxide was confirmed by reflectance UV-visible and fluorescence spectroscopies. The activity of the prepared sample was evaluated for photocatalytic removal of the 2,4-D. The photocatalytic activity of the $\mathrm{TiO}_{2}$ increased with the increase of copper oxide loading up to $0.5 \mathrm{~mol} \%$. Unfortunately, the higher loading amount of copper oxide resulted in the lower photocatalytic activity. This study suggested that the higher photocatalytic activities obtained on the low loading samples were due to the lower electron-hole recombination.
\end{abstract}

Keywords: $\mathrm{P} 25 \mathrm{TiO}_{2}$, copper oxide, impregnation, photocatalyst, 2,4-D herbicide

\begin{abstract}
Abstrak
Asid 2,4-diklorofenoksiasetik (2,4-D) adalah herbisid biasa yang telah digunakan secara meluas. Oleh kerana penggunaan yang berlebihan, herbisid 2,4-D boleh menyebabkan pencemaran di kawasan pertanian dan sistem air. Dalam kajian ini, satu kaedah pengisitepuan yang mudah telah digunakan untuk mengubahsuai nanozarah titanium dioksida komersial $\left(\mathrm{P} 25 \mathrm{TiO}_{2}\right)$ dengan kuprum oksida. Sampel yang disediakan telah dicirikan dengan XRD, spektroskopi pantulan serakan ultra lembayung-cahaya nampak, dan spektroskopi pendarfluor. Didapati pengubahsuaian $\mathrm{P} 25 \mathrm{TiO}_{2}$ dengan kuprum oksida tidak memberi kesan yang signifikan kepada struktur kristal P25 TiO . Sebaliknya, kehadiran kuprum oksida telah disahkan oleh spektroskopi pantulan serakan ultra lembayung-cahaya nampak. Aktiviti sampel telah diuji untuk penyingkiran 2,4D. Aktiviti fotomangkin $\mathrm{TiO}_{2}$ meningkat dengan peningkatan jumlah kuprum oksida kepada 0.5 mol\%. Malangnya, jumlah kuprum oksida yang lebih tinggi menghasilkan aktiviti fotomangkin yang lebih rendah. Kajian ini mencadangkan bahawa aktiviti fotomangkin yang tinggi diperolehi pada sampel loading rendah adalah disebabkan oleh penggabungan elektron-lubang yang lebih rendah
\end{abstract}

Kata kunci: P25 $\mathrm{TiO}_{2}$, kuprum oksida, pengisitepuan, fotomangkin, 2,4-D herbisid 


\section{Leny Yuliati et al: MODIFICATION OF TITANIUM DIOXIDE NANOPARTICLES WITH COPPER OXIDE CO-CATALYST FOR PHOTOCATALYTIC DEGRADATION OF 2,4-DICHLOROPHENOXYACETIC ACID}

\section{Introduction}

The 2,4-dichlorophenoxyacetic acid (2,4-D) is one of the most used herbicides in the world and has been used since the 1940s. The 2,4-D is used widely to control broadleaf weeds in a variety of settings from crops, rights-of-way, lawns, forests to aquatic settings. In 1986, the International Agency for Cancer Research (IARC) classified the chlorophenoxy herbicides as a Group 2B (possible) carcinogen. Since then, various studies have been done on the toxicity and carcinogenicity of the 2,4-D. Recently, the 2,4-D epidemiology literature has been qualitatively reviewed [1]. Even though no convincing evidence for any chronic adverse effect of 2,4-D in human, studies in the removals of the 2,4-D in order to prevent the negative effects of the 2,4-D towards human and environment are still in progress.

One of the simple methods to remove the 2,4-D from water is by adsorption process. Some adsorbents have been reported to give good performance to adsorb the 2,4-D, such as the layered double hydroxides (LDH) [2 -5] and mesoporous materials [6] due to the large surface area, high anion capacity, and good thermal stability. However, rather than removing the 2,4-D by an adsorption process, degradation of the 2,4-D would be a great advantage to solve the environment problems. Degradation of the 2,4-D could be achieved by introducing the electrochemical assistance to a micobiological reduction system [7], and photooxidation via Fenton reaction and in the presence of strong oxidant such as hydrogen peroxide [8]. However, from the point of view of sustainability and environmentally safe process, photocatalytic reaction would be the promising method to degrade the 2,4-D herbicide [ 9 - 13]. Some studies also reported the combined method to degrade 2,4-D by the photocatalytic reactions with the use of strong oxidants and microwave $[9,10]$.

In general, photocatalytic removal of environmental pollutants has been a topic of great interest over the years [14]. One of the most widely used materials for photocatalytic degradation of environmental pollutants is titanium dioxide $\left(\mathrm{TiO}_{2}\right)$. As a photocatalyst, $\mathrm{TiO}_{2}$ has a range of useful features, including high photocatalytic activity, stability, low toxicity, ready availability and low cost [15]. While $\mathrm{TiO}_{2}$ is one of the most active catalysts for the degradation of a wide range of organic compounds, its catalytic activity should be further improved. Hence, there have been a great number of studies to modify the $\mathrm{TiO}_{2}$ based photocatalysts. It has been reported that the $\mathrm{TiO}_{2}$ bound with $\mathrm{TiO}_{2}$ sol with the help of polymeric bonds showed better photocatalytic activity for degradation of 2,4-D than the unmodified $\mathrm{TiO}_{2}$, owing to the better distributions of photons [11]. Another study reported that the addition of reduced graphene oxide and $\mathrm{CuInS}_{2}$ on the $\mathrm{TiO}_{2}$ improved its activity for degradation of the 2,4-D [12]. The addition of $\mathrm{Ag} /$ reduced graphene oxide was also reported increasing the activity of $\mathrm{TiO}_{2}$ for the 2,4-D degradation [13]. The improved activity was closely related to the effective carriers separation and large adsorption capacity for the 2,4-D [12,13].

While several studies have been reported to modify $\mathrm{TiO}_{2}$ with noble metals, transition metal oxides and non-metal ions [15-18], in particular, it has been shown that transition metal oxides such as copper oxide have the potential of enhancing the photocatalytic activity of $\mathrm{TiO}_{2}[19-21]$. When applied to $\mathrm{TiO}_{2}$ on the optimal composition, phase and size, these transition metal oxide nanoparticles can act as effective co-catalysts that improve the efficiency of $\mathrm{TiO}_{2}$ photocatalysis. In the present work, a simple impregnation method was used to grow copper oxide nanoparticles on the surface of commercial $\mathrm{P} 25 \mathrm{TiO}_{2}$ particles. The amount of copper incorporated on the surface of the $\mathrm{P} 25 \mathrm{TiO}_{2}$ particles was varied in the range of 0.1 to $5 \mathrm{~mol} \%$. The effect of $\mathrm{Cu}$ loading on the photocatalytic activity of $\mathrm{TiO}_{2}$ to degrade the 2,4-D was investigated.

\section{Preparation of photocatalysts}

\section{Materials and Methods}

$\mathrm{P} 25 \mathrm{TiO}_{2}$ (Evonik) and copper(II) nitrate trihydrate (Aldrich, $99-104 \%$ ) were used as received without any treatments. The required amount of copper(II) nitrate trihydrate was dissolved into $20 \mathrm{ml}$ of distilled water. Then, the $\mathrm{P} 25 \mathrm{TiO}_{2}(1 \mathrm{~g})$ was dispersed in the copper nitrate solution by sonicating the mixture for 10 minutes. Under vigorous stirring, the resultant mixture was heated at $80{ }^{\circ} \mathrm{C}$ until the solvent was removed. The dried mixture was ground to a fine powder and calcined at $500{ }^{\circ} \mathrm{C}$ for 4 hours. The resultant powder was ground and stored under ambient conditions. The samples were labeled as $x \mathrm{~mol} \% \mathrm{Cu} / \mathrm{P} 25 \mathrm{TiO}_{2}$, with $x$ showed the ratio of $\mathrm{Cu}$ to $\mathrm{Ti}(\mathrm{mol} \%)$ and varied in the range of $0.1-5 \mathrm{~mol} \%$. For comparison, the $\mathrm{P} 25 \mathrm{TiO}_{2}$ was also treated in the same manner to the samples, except for the addition of the copper(II) nitrate trihydrate. 


\section{Characterizations}

X-ray Diffraction (XRD, Bruker AXS Diffrac plus release 2000) was used to identify the structure of the prepared photocatalysts. The optical properties of the samples were analyzed by an Avantes spectrophotometer AvaSpecULS2048 using a reflection probe holder with angle of $45^{\circ}$ and PTFE-coated white material as the reference sample. The emission spectra were measured at room temperature on a Fluorescence Spectroscopy JASCO FP8500. The spectra were monitored at excitation wavelength of $218 \mathrm{~nm}$. The morphology and particle size of the samples were investigated by a transmission electron microscopy (TEM, JEM-2100) at an accelerating voltage of $200 \mathrm{kV}$. The sample was dispersed well in ethanol and then, put on a carbon-coated copper grid.

\section{Photocatalytic activity test}

The prepared samples were evaluated for removal of 2,4-D at room temperature under UV light irradiation. Prior to the irradiation, the sample $(50 \mathrm{mg})$ was dispersed in $2,4-\mathrm{D}$ solution $(50 \mathrm{~mL}, 0.5 \mathrm{mM})$ and stirred in the dark condition for 1 hour to achieve the adsorption-desorption equilibrium. The reaction was carried out for 1 hour under irradiation by a $200 \mathrm{~W}$ Xe-Hg lamp, which light intensity was $15 \mathrm{~mW} \mathrm{~cm}$ and it was equipped with an IR cut off filter. The remaining amount of 2,4-D after each reaction was determined by UV-Visible spectrophotometer using a Thermo Scientific Genesys 10S. The monitored wavelength was $283 \mathrm{~nm}$. The percentage of 2,4-D removal was then calculated from the ratio of concentrations between the reacted and the initial 2,4-D.

\section{Properties of $\mathrm{Cu} / \mathrm{P} 25 \mathrm{TiO}_{2}$ samples}

\section{Results and Discussion}

Figure 1 shows the XRD patterns of $\mathrm{P} 25 \mathrm{TiO}_{2}$ and the prepared $\mathrm{Cu} / \mathrm{P} 25 \mathrm{TiO}_{2}$ samples. All samples showed the diffraction peaks at $2 \theta$ of 25.30 and $27.43^{\circ}$, corresponding to the (101) plane of anatase $\mathrm{TiO}_{2}$ and (110) plane of rutile $\mathrm{TiO}_{2}$, respectively. These XRD patterns clearly suggested the presence of both anatase and rutile phases in the samples. However, no appreciable diffraction peak of copper oxide phase was observed on all of the $\mathrm{Cu} / \mathrm{P} 25 \mathrm{TiO} 2$ samples. This was mostly likely due to the small amount of copper oxide present in the sample. In addition, a high degree of dispersion of copper oxide on the $\mathrm{TiO}_{2}$ support would result in the small particle size of the metal oxide, which would be beyond the detection limit of XRD.

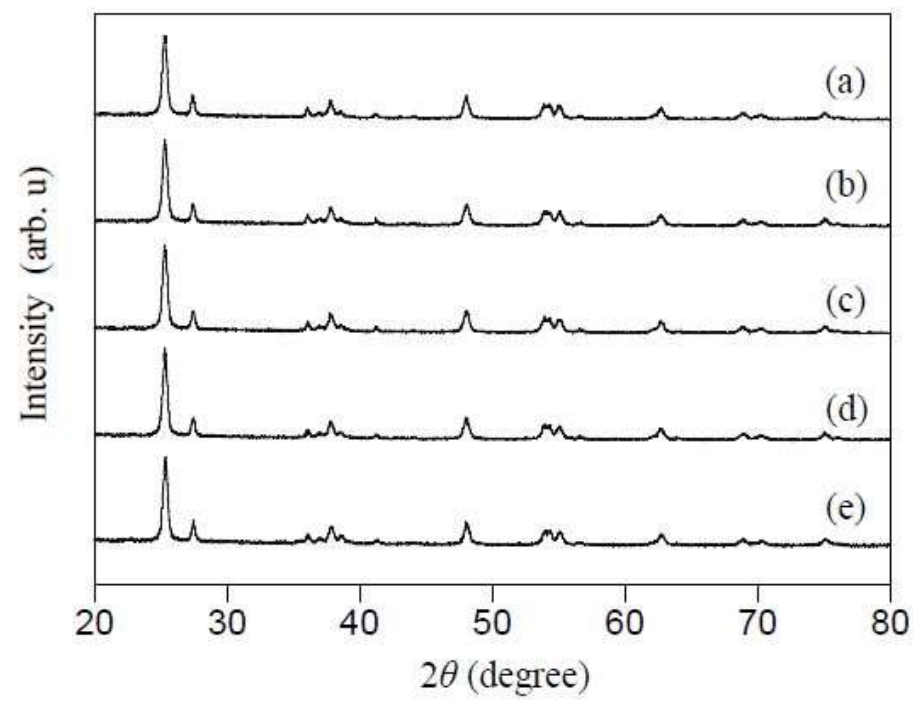

Figure 1. XRD patterns of (a) $\mathrm{P} 25 \mathrm{TiO}_{2}$, (b) $0.1 \mathrm{~mol} \% \mathrm{Cu} / \mathrm{P} 25 \mathrm{TiO}_{2}$, (c) $0.5 \mathrm{~mol} \% \mathrm{Cu} / \mathrm{P} 25 \mathrm{TiO}$, (d) $1 \mathrm{~mol} \%$ $\mathrm{Cu} / \mathrm{P} 25 \mathrm{TiO}_{2}$, and (e) $5 \mathrm{~mol} \% \mathrm{Cu} / \mathrm{P} 25 \mathrm{TiO}_{2}$ samples. 


\section{Leny Yuliati et al: MODIFICATION OF TITANIUM DIOXIDE NANOPARTICLES WITH COPPER OXIDE CO-CATALYST FOR PHOTOCATALYTIC DEGRADATION OF 2,4-DICHLOROPHENOXYACETIC ACID}

As shown in Figure 1, the XRD patterns of the $\mathrm{Cu} / \mathrm{P} 25 \mathrm{TiO}_{2}$ samples were very similar to that of the $\mathrm{P} 25 \mathrm{TiO}_{2}$ sample. This result showed that the incorporation of copper oxide did not affect significantly the crystal structure of $\mathrm{P} 25 \mathrm{TiO}_{2}$. Table 1 shows the crystallite size of anatase and the anatase to rutile ratio of the $\mathrm{P} 25 \mathrm{TiO}_{2}$ and the prepared $\mathrm{Cu} / \mathrm{P} 25 \mathrm{TiO}_{2}$ samples. The crystallite size for anatase and rutile phase was determined by a Scherrer equation as shown in Equation 1, using the most intense peak of anatase (101) around $2 \theta$ of $25.3^{\circ}$ and rutile (110) around $2 \theta$ of $27.4^{\circ}$, respectively.

$$
t=\frac{K \lambda}{\beta \cos \theta}
$$

where $t$ is the average crystallite size in $\mathrm{nm}$, while $K$ is dimensionless shapes factor generally taken as $0.89, \lambda$ is the wavelength of the X-ray equals to $1.542 \AA, \beta$ is full width at half maximum (FWHM) at $2 \theta$ of 25.3 or $27.4^{\circ}$ and $\theta$ is Bragg's angle. The anatase to rutile ratio was also calculated based on the intensity of the most intense peaks at around $2 \theta$ of 25.3 and $27.4^{\circ}$ for anatase (101) and rutile (110), respectively, as shown in Equation 2.

$$
A(\%)=\frac{100 \times I_{A}}{I_{A}+1.265 \times I_{R}}
$$

where $A(\%)$ is the percentage of anatase, $I_{\mathrm{A}}$ and $I_{\mathrm{R}}$ correspond to the intensity of the anatase (101) and rutile (110) reflections, respectively.

As listed in Table 1, the crystallite size of $\mathrm{P} 25 \mathrm{TiO}_{2}$ for both anatase and rutile phase was only slightly increased upon the addition of copper oxide. The average crystallite size for anatase phase was in the range of 17-21 nm, while for rutile phase was in the range of $60-72 \mathrm{~nm}$. In addition, the anatase to rutile phase ratio of $\mathrm{P}_{2} 5 \mathrm{TiO}_{2}$ likewise was not much affected by the incorporation of copper oxide. In order to support the crystallite size data, TEM images for the $\mathrm{P} 25 \mathrm{TiO}_{2}$ and $0.5 \mathrm{~mol} \% \mathrm{Cu} / \mathrm{P} 25 \mathrm{TiO}_{2}$ are shown in Figure 2. The $\mathrm{P} 25 \mathrm{TiO}_{2}$ showed irregular polyhedral shape nanoparticles (Fig. 2(a)). Most of the particles have size in the range of $15-25 \mathrm{~nm}$ due to the presence of anatase phase, while larger particles in the range of 50-70 nm were due to the presence of rutile phase. On the other hand, Figure 2(b) showed that no remarkable change in morphology and particle size could be observed on the $0.5 \mathrm{~mol} \% \mathrm{Cu} / \mathrm{P} 25 \mathrm{TiO}_{2}$. These results are in good agreement with the calculated average crystallite size from the XRD patterns shown in Table 1.

Table 1. Crystallite size and anatase to rutile ratio for $\mathrm{P} 25 \mathrm{TiO}_{2}$ and $\mathrm{Cu} / \mathrm{P} 25 \mathrm{TiO}_{2}$ samples

\begin{tabular}{ccccc}
\hline \multirow{2}{*}{ Entry } & \multirow{2}{*}{ Sample } & \multicolumn{2}{c}{ Crystallite size $(\mathbf{n m})^{\boldsymbol{a}}$} & \\
\cline { 2 - 4 } & & Anatase & Rutile & \\
& & & \\
1 & $\mathrm{P} 25 \mathrm{TiO}_{2}$ & 17.1 & 60.2 & $72: 28$ \\
2 & $0.1 \mathrm{~mol} \% \mathrm{Cu} / \mathrm{P} 25 \mathrm{TiO}_{2}$ & 18.1 & 67.8 & $74: 26$ \\
3 & $0.5 \mathrm{~mol} \% \mathrm{Cu} / \mathrm{P} 25 \mathrm{TiO}_{2}$ & 18.5 & 71.9 & $74: 26$ \\
4 & $1 \mathrm{~mol} \% \mathrm{Cu} / \mathrm{P} 25 \mathrm{TiO}_{2}$ & 18.7 & 59.9 & $76: 24$ \\
5 & $5 \mathrm{~mol} \% \mathrm{Cu} / \mathrm{P} 25 \mathrm{TiO}_{2}$ & 20.3 & 62.0 & $74: 26$ \\
\hline
\end{tabular}

${ }^{a}$ Estimated by the Scherrer equation shown in the Eq. 1.

${ }^{b}$ Estimated by the formula shown in the Eq. 2 . 

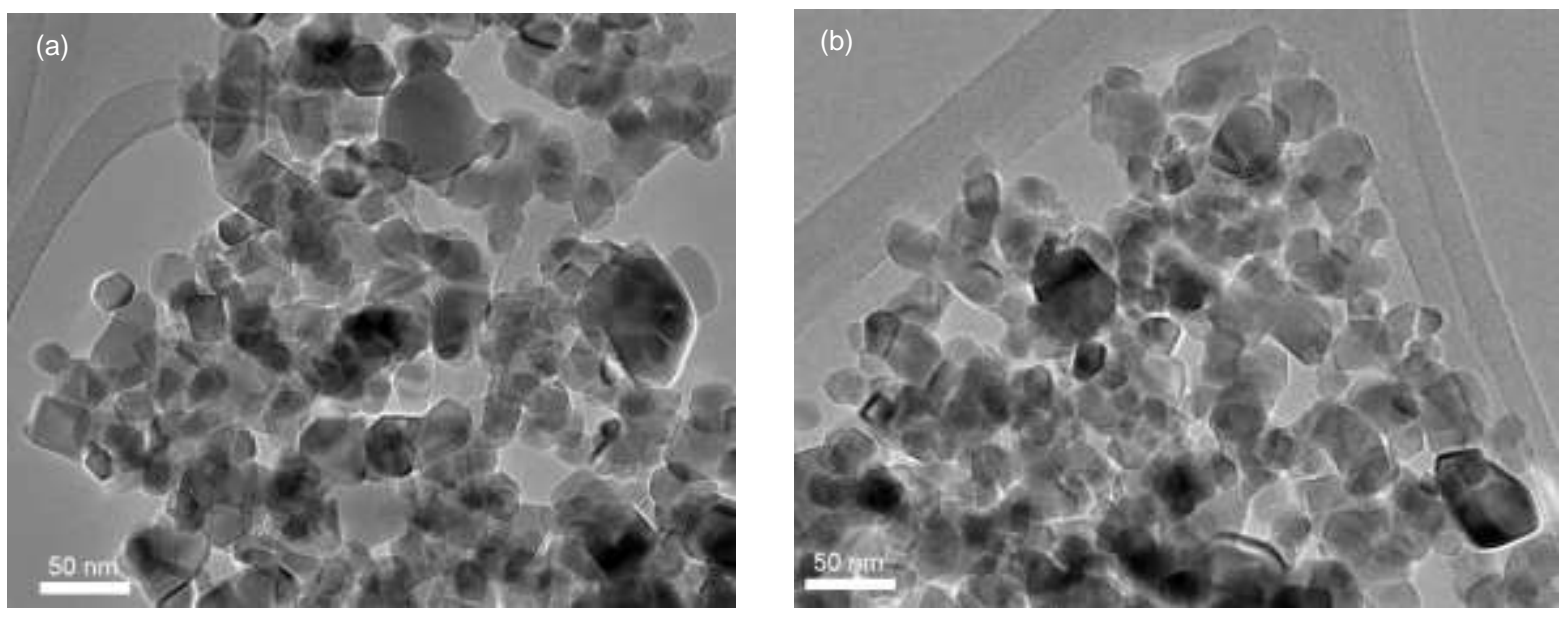

Figure 2. TEM images of (a) $\mathrm{P} 25 \mathrm{TiO}_{2}$ and (b) $0.5 \mathrm{~mol} \% \mathrm{Cu} / \mathrm{P} 25 \mathrm{TiO}_{2}$ samples.

Figure 3 shows the reflectance UV-Vis absorption spectra of the $\mathrm{P} 25 \mathrm{TiO}_{2}$ and $\mathrm{Cu} / \mathrm{P} 25 \mathrm{TiO}_{2}$ samples. The unmodified $\mathrm{P} 25 \mathrm{TiO}_{2}$ sample has white colour as can be reflected in its UV-Vis absorption spectrum that displayed very low absorption intensity in the visible region of the spectrum (Fig. 3(a)). The addition of copper oxide resulted in the colour change from white to green. The colour became darker with the increase of the copper oxide loading. These changes could be observed in Figure 2, in which the $\mathrm{Cu} / \mathrm{P} 25 \mathrm{TiO}_{2}$ samples gave additional absorption in the visible light region and the absorbance increased with the increase of the copper oxide loading amount. The absorbance in the visible light region would be originated from the $\mathrm{d}-\mathrm{d}$ transitions of the $\mathrm{Cu}^{2+}$ system [19], which were present on the surface of copper oxide modified $\mathrm{TiO}_{2}$. While the $\mathrm{Cu} / \mathrm{P} 25 \mathrm{TiO}_{2}$ samples with low loadings of copper oxide did not much influence the band gap of the $\mathrm{TiO}_{2}$, sample with high loading $5 \mathrm{~mol} \% \mathrm{Cu} / \mathrm{P}_{2} 5 \mathrm{TiO}_{2}$ slightly shifted the band edge absorption of $\mathrm{P}_{2} 5 \mathrm{TiO}_{2}$ to longer wavelength. The shift indicated that some copper metal ions might alter the band gap of $\mathrm{TiO}_{2}[16,17]$.

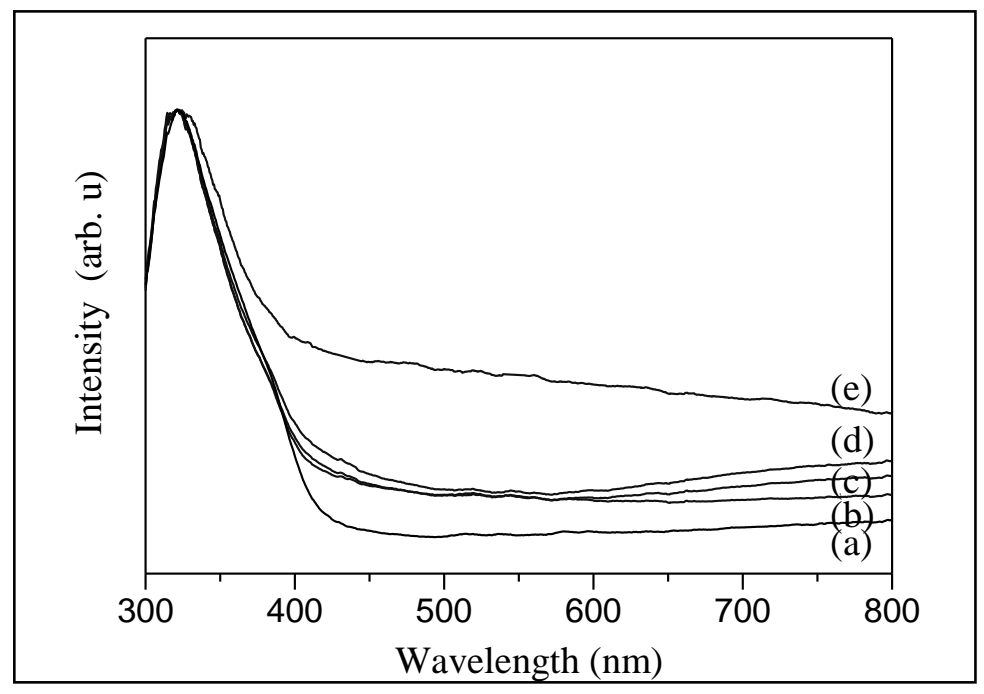

Figure 3. Normalized reflectance UV-Visible spectra of (a) $\mathrm{P}_{2} 5 \mathrm{TiO}_{2}$, (b) $0.1 \mathrm{~mol} \% \mathrm{Cu} / \mathrm{P} 25 \mathrm{TiO}_{2}$, (c) $0.5 \mathrm{~mol} \%$ $\mathrm{Cu} / \mathrm{P} 25 \mathrm{TiO}_{2}$, (d) $1 \mathrm{~mol} \% \mathrm{Cu} / \mathrm{P} 25 \mathrm{TiO}_{2}$, and (e) $5 \mathrm{~mol} \% \mathrm{Cu} / \mathrm{P} 25 \mathrm{TiO}_{2}$ samples 


\section{Leny Yuliati et al: MODIFICATION OF TITANIUM DIOXIDE NANOPARTICLES WITH COPPER OXIDE CO-CATALYST FOR PHOTOCATALYTIC DEGRADATION OF 2,4-DICHLOROPHENOXYACETIC ACID}

In order to study the interaction between the $\mathrm{P} 25 \mathrm{TiO}_{2}$ and the copper oxide, the emission spectra of the samples were measured at the excitation of $\mathrm{P}_{25} \mathrm{TiO}_{2}$, which was at $218 \mathrm{~nm}$. Figure 4 shows the emission spectra of P25 $\mathrm{TiO}_{2}$ and the $\mathrm{Cu} / \mathrm{P} 25 \mathrm{TiO}_{2}$ samples. It was obvious that the emission intensity of $\mathrm{P} 25 \mathrm{TiO}_{2}$ was reduced with the addition of copper oxide. The emission intensity was further reduced with the further increase of the copper oxide loading. This result clearly showed that there were interactions between $\mathrm{P} 25 \mathrm{TiO}_{2}$ and the added copper oxide. Since emission intensity can be corresponded to the electron-hole recombination, the decreased emission intensity can be assigned to the suppression of electron-hole recombination.

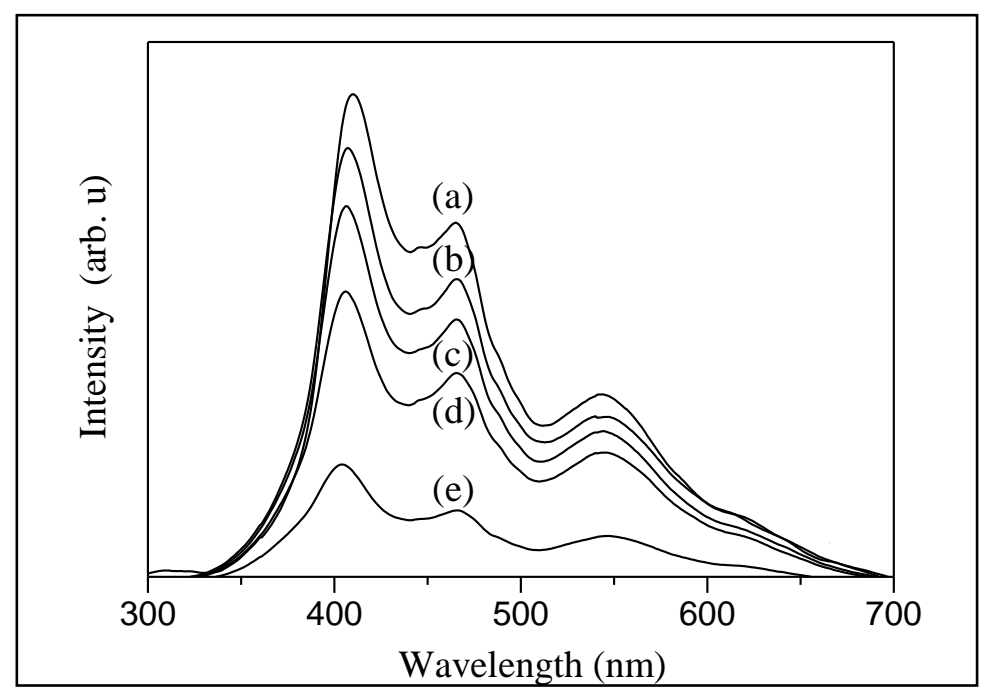

Figure 4. Emission spectra of (a) $\mathrm{P} 25 \mathrm{TiO}_{2}$, (b) $0.1 \mathrm{~mol} \% \mathrm{Cu} / \mathrm{P} 25 \mathrm{TiO}_{2}$, (c) $0.5 \mathrm{~mol} \% \mathrm{Cu} / \mathrm{P} 25 \mathrm{TiO}_{2}$, (d) $1 \mathrm{~mol} \%$ $\mathrm{Cu} / \mathrm{P} 25 \mathrm{TiO}_{2}$, and (e) $5 \mathrm{~mol} \% \mathrm{Cu} / \mathrm{P} 25 \mathrm{TiO}_{2}$ samples, monitored at excitation wavelength of $218 \mathrm{~nm}$

As discussed previously, copper ions might alter the band gap energy of $\mathrm{P} 25 \mathrm{TiO}_{2}$. Therefore, copper oxide might act as the co-catalyst to trap electron, thus enhancing the charge separation in the $\mathrm{P} 25 \mathrm{TiO}_{2}$ that would lead to the enhanced activity. However, if the amount of copper oxide was too high, it would reduce the electrons in the conduction band of the $\mathrm{P} 25 \mathrm{TiO}_{2}$ that might reduce the efficiency. Moreover, the large amount of copper oxide might also block the active sites of the $\mathrm{P}_{25} \mathrm{TiO}_{2}$ and reduce the photocatalytic activity. In other words, there would be an optimum amount of copper oxide that would give the optimum activity, which would be explained in the following part.

\section{Photocatalytic activities of $\mathrm{Cu} / \mathrm{P25} \mathrm{TiO}_{2}$ samples}

Figure 5 shows the photocatalytic removal of 2,4-D on the $\mathrm{P} 25 \mathrm{TiO}_{2}$ and $\mathrm{Cu} / \mathrm{P} 25 \mathrm{TiO}_{2}$. It can be clearly shown that after 1 hour reaction, the photocatalytic activity of $\mathrm{TiO}_{2}$ increased from 48.3 to $59.4 \%$ with the increase of copper oxide loading up to $0.5 \mathrm{~mol} \%$. Unfortunately, the higher loading amount of copper oxide resulted in the lower photocatalytic activity. When the loading amount was $5 \mathrm{~mol} \%$, the activity decreased to $25.8 \%$. This result clearly suggested that the small amount of copper oxide, which was $0.5 \mathrm{~mol} \%$, was the optimum amount in this study to give the highest activity for the $\mathrm{Cu} / \mathrm{P} 25 \mathrm{TiO}_{2}$. The higher photocatalytic activity would be originated from the lower electron-hole recombination. On the other hand, the high loading amount of copper oxide might reduce the electrons in the conduction band of $\mathrm{P} 25 \mathrm{TiO}_{2}$ or might block the active surface of $\mathrm{P} 25 \mathrm{TiO}_{2}$, thus reduced the photocatalytic activity. Therefore, the optimum amount of copper oxide that would result in the optimum activity would be related to the optimum electron-hole separation, without reducing electrons in the conduction band of $\mathrm{P}_{2} 5 \mathrm{TiO}_{2}$ and/or blocking active sites of the $\mathrm{TiO}_{2}$. Similar results have been reported elsewhere [19-21]. The high amount of copper oxide may give masking effect on the $\mathrm{P} 25 \mathrm{TiO}_{2}$, which prevented the UV light source to reach the active sites of $\mathrm{TiO}_{2}$. 


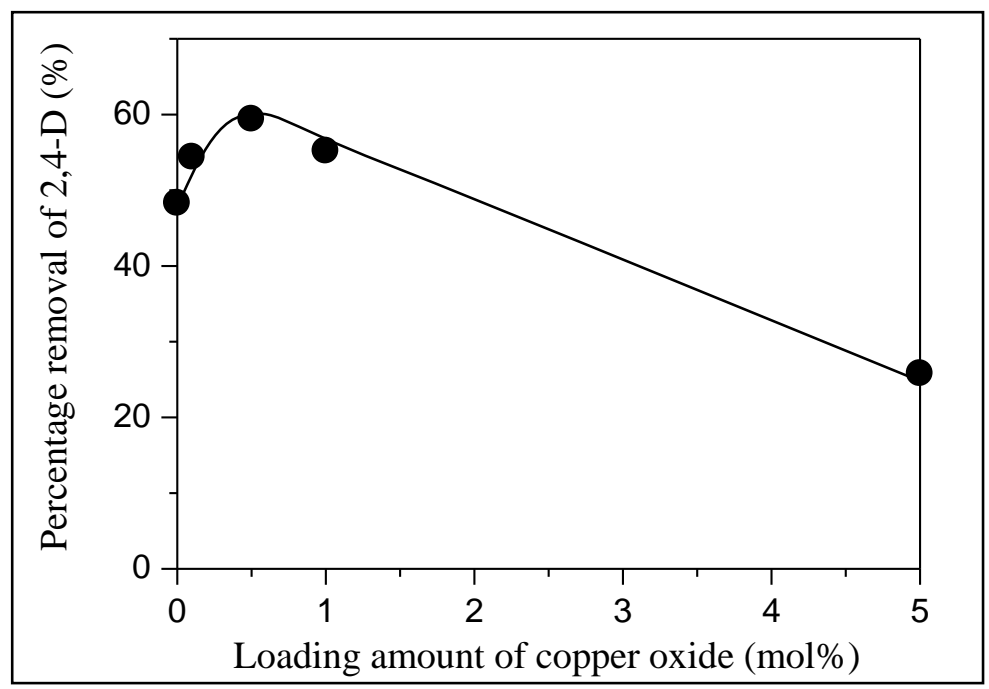

Figure 5. Photocatalytic removal of 2,4-D herbicide on the $\mathrm{P} 25 \mathrm{TiO}_{2}$ and $\mathrm{Cu} / \mathrm{P} 25 \mathrm{TiO}_{2}$ samples.

\section{Conclusion}

The $\mathrm{Cu} / \mathrm{P} 25 \mathrm{TiO}_{2}$ samples were prepared successfully by an impregnation method. The addition of copper oxide did not much affect the crystallite size and the crystal phase of the $\mathrm{P}_{2} 5 \mathrm{TiO}_{2}$. On the other hand, the addition of copper oxide increased the visible light absorption and slightly altered the band edge absorption of $\mathrm{P}_{25} \mathrm{TiO}_{2}$. Copper oxide also reduced the emission intensity, suggesting that optimum amount of copper oxide might act as good co-catalyst to trap electros, thus suppress the electron-hole recombination. The $0.5 \mathrm{~mol} \%$ was found to be the optimum amount of copper oxide that enhance the activity of $\mathrm{P} 25 \mathrm{TiO}_{2}$ for the photocatalytic removal of 2,4-D herbicide.

\section{Acknowledgement}

The research leading to these results has received funding from the European Union Seventh Framework Program (EU-FP7) under 4G-PHOTOCAT grant (agreement no.: 309636). This work has been also financially supported by the Ministry of Higher Education (MOHE) and Universiti Teknologi Malaysia (UTM, Malaysia) through the international contract matching grant (cost center code: R.J130000.7626.4C035).

\section{References}

1. Burns, C. J., and Swaen, G. M. H. (2012). Review of 2,4-Dichlorophenoxyacetic Acid (2,4-D) Biomonitoring and Epidemiology. Critical Reviews in Toxicology, 42 (9): 768 - 786.

2. Legrouri, A., Lakraimi, M., Barroug, A., De Roy, A. and Besse, J. (2005). Removal of the Herbicide 2,4-Dichlo-rophenoxyacetate from Water to Zinc-Aluminium-Chloride Layered Double Hydroxides, Water Research, 39 (15): 3441 - 3448.

3. Chao, Y.-F., Chen, P.-C. and Wang, S.-L. (2008). Adsorption of 2,4-D on Mg/Al- $\mathrm{NO}_{3}$ Layered Double Hydroxides with Varying Layer Charge Density, Applied Clay Science, 40 (1-4): 193 - 200.

4. Chao, Y. F., Lee, J. J. and Wang, S. L. (2009). Preferential Adsorption of 2,4-Dichlorophenoxyacetate from Associated Binary-Solute Aqueous Systems by $\mathrm{Mg} / \mathrm{Al}-\mathrm{NO}_{3}$ Layered Double Hydroxides with Different Nitrate Orientations, Journal of Hazardous Materials, 165 (1-3): 846 - 852.

5. Nejati, K., Davary, S. and Saati, M. (2013). Study of 2,4-Dichlorophenoxyacetic Acid (2,4-D) Removal by $\mathrm{Cu}-\mathrm{Fe}-\mathrm{Layered}$ Double Hydroxide from Aqueous Solution. Applied Surface Science, 280: 67-73.

6. Momcilovic, M. Z., Randelovic, M. S., Zarubica, A. R., Onjia, A. E., Kokunešoski, M., and Matovic, B. Z. (2013). SBA-15 Templated Mesoporous Carbons for 2,4-Dichlorophenoxyacetic Acid Removal. Chemical Engineering Journal, 220: 276 - 283. 
Leny Yuliati et al: MODIFICATION OF TITANIUM DIOXIDE NANOPARTICLES WITH COPPER OXIDE CO-CATALYST FOR PHOTOCATALYTIC DEGRADATION OF

2,4-DICHLOROPHENOXYACETIC ACID

7. Zhang, J. L., Cao, Z.P., Zhang, H.W., Zhao, L. M., Sun, X. D. and Mei, F. (2013). Degradation Characteristics of 2,4-Dichlorophenoxyacetic Acid in Electro-Biological System. Journal of Hazardous Materials, 262: 137 142.

8. Kwan, C. Y. and Chu, W. (2004). A Study of the Reaction Mechanisms of the Degradation of 2,4-Dichlorophenoxyacetic Acid by Oxalate-Mediated Photooxidation. Water Research, 38 (19): 4213 -4221.

9. Pei, C. C. and Chu, W. (2013). The Photocatalyic Degradation and Modeling of 2,4-Dichlorophenoxyacetic Acid by Bismuth Tungstate/Peroxide. Chemical Engineering Journal, 223: 665 - 669.

10. Lee, H., Park, S.H., Park,Y.-K., Kim, S.-J., Seo, S.-G., Ki, S.J. and Jung, S.-C. (2014). Photocatalytic Reactions of 2,4-Dichlorophenoxyacetic Acid using a Microwave-Assisted Photocatalysis System. Chemical Engineering Journal. 278: 259 - 264.

11. Vega, A. A., Imoberdorf, G. E. and Mohseni, M. (2011). Photocatalytic Degradation of 2,4-Dichlorophenoxy acetic Acid in a Fluidized Bed Photoreactor with Composite Template-Free $\mathrm{TiO}_{2}$ Photocatalyst. Applied Catalysis A: General, 405 (1-2): 120 -128.

12. Liu, X., Tang, Y., Luo, S., Wang, Y., Zhang, X., Chen, Y. and Liu, C. (2013). Reduced Graphene Oxide and $\mathrm{CuInS}_{2} \mathrm{Co}$-Decorated $\mathrm{TiO}_{2}$ Nanotube Arrays for Efficient Removal of Herbicide 2,4-Dichlorophenoxyacetic Acid from Water. Journal of Photochemistry and Photobiology A: Chemistry, 262: 22 - 27.

13. Tang, Y., Luo, S., Teng, Y., Liu, C., Xu, X., Zhang, X. and Chen, L. (2012). Efficient Removal of Herbicide 2,4-Dichlorophenoxyacetic Acid from Water using Ag/Reduced Graphene Oxide Co-Decorated $\mathrm{TiO}_{2}$ Nanotube Arrays. Journal of Hazardous Materials, 241-242: 323 - 330.

14. Malato, S., Fernández-Ibáñez, P., Maldonado, M. I., Blanco, J. and Gernjak, W. (2009). Decontamination and Disinfection of Water by Solar Photocatalysis: Recent Overview and Trends. Catalysis Today, 147 (1): 1-59.

15. Teh, C. M. and Mohamed, A. R. (2011). Roles of Titanium Dioxide and Ion-doped Titanium Dioxide on Photocatalytic Degradation of Organic Pollutants (Phenolic Compounds and Dyes) in Aqueous Solutions: A Review. Journal of Alloys and Compounds, 509 (5): 1648 - 1660.

16. Choi, W., Termin, A. and Hoffmann, M. R. (1994). The Role of Metal Ion Dopants in Quantum-Sized TiO Correlation etween Photoreactivity and Charge Carrier Recombination Dynamics. The Journal of Physical Chemistry, 98 (51): 13669 - 13679.

17. Di Paola, A., Marcì, G., Palmisano, L., Schiavello, M., Uosaki, K., Ikeda, S. and Ohtani, B. (2001). Preparation of Polycrystalline $\mathrm{TiO}_{2}$ Photocatalysts Impregnated with Various Transition Metal Ions: Characterization and Photocatalytic Activity for the Degradation of 4-Nitrophenol. The Journal of Physical Chemistry B, 106 (3): 637 - 645.

18. Dvoranová, D., Brezová, V., Mazúr, M. and Malati, M. A. (2002). Investigations of Metal-Doped Titanium Dioxide Photocatalysts. Applied Catalysis B: Environmental, 37 (2): 91-105.

19. Chiang, K., Amal, R. and Tran, T. (2002). Photocatalytic Degradation of Cyanide using Titanium Dioxide Modified with Copper Oxide. Advances in Environmental Research, 6 (4): 471 - 485.

20. Tseng, I.-H., Chang, W.-C. and Wu, J. C. S. (2002). Photoreduction of $\mathrm{CO}_{2}$ Using Sol-Gel Derived Titania and Titania-Supported Copper Catalysts. Applied Catalysis B: Environmental, 37 (1): 37 - 48.

21. Slamet, Nasution, H.W., Purnama, E., Kosela, S. and Gunlazuardi, J. (2005). Photocatalytic Reduction of $\mathrm{CO}_{2}$ on Copper-Doped Titania Catalysts Prepared by Improved-Impregnation Method. Catalysis Communication, 6 (5): $313-319$. 